\title{
USE OF DIGITAL IMAGES FOR EVALUATING SOIL COMPACTION IN THE CULTURE OF BEANS
}

\section{Uso de imagens digitais para avaliação da compactação do solo na cultura do feijão}

\author{
Daniel Mariano Leite ${ }^{1}$, Luciano Baião Vieira² ${ }^{2}$ Haroldo Carlos Fernandes ${ }^{2}$, \\ José Eustáquio Souza Carneiro ${ }^{3}$, Elpídio Inácio Fernandes Filho ${ }^{4}$, Nerilson Terra Santos ${ }^{5}$
}

\begin{abstract}
Bean yield in Brazil is considered low, around $820 \mathrm{~kg} \mathrm{ha}^{-1}$, reaching values above $3000 \mathrm{~kg} \mathrm{ha}^{-1}$, there are several environmental factors which may limit the performance of this culture, especially those related to the soil. The present work aimed to evaluate soil compactions in bean culture of different soil management systems, by means of digital images. This study took place at the Federal University of Viçosa, randomized block design with six replications was used and four treatments, (direct planting, conventional preparation, minimum plantation using grade crusher-leveler and minimum plantation using scarificator), were evaluated. The spectral responses using the vegetation indexes (NDVI, RS, GNDVI, VARI, WDRVI and SAVI) were evaluated, calculated from digital numbers of the images and the values were estimated from the reflectance. For obtainning the images, a platform containing two digital cameras, one sensitive in the region of visible (RGB) and another sensitive to the region of proximal infrared were used, this platform was attached to a helium-inflatable balloon. The vegetation indexes obtained from the values of digital numbers of images were only able to defer treatments 70 days after plantation. However, indexes obtained from the reflectance, deferred treatments at 34 and 70 days after planting.
\end{abstract}

Index terms: Remote sensing, soil management, unmanned balloon.

\section{RESUMO}

A produtividade do feijoeiro no Brasil é considera baixa entorno de $820 \mathrm{~kg} \mathrm{ha}^{-1}$, podendo atingir valores acima de $3.000 \mathrm{~kg} \mathrm{ha}^{-1}$, vários fatores ambientais podem limitar o bom desempenho da cultura, principalmente os relacionados ao solo. Sendo assim objetivouse com a realização deste trabalho avaliar a compactação do solo na cultura do feijoeiro em diferentes sistemas de manejo do solo, por meio de imagens digitais. Este trabalho foi realizado na Universidade Federal de Viçosa, utilizou-se o delineamento em blocos ao acaso com seis repetições, sendo quatros tratamentos avaliados (plantio direto, preparo convencional, cultivo mínimo utilizando grade niveladora-destorroadora e cultivo mínimo utilizando escarificador). Foram avaliados a resposta espectral utilizando índices de vegetação (NDVI, RS, GNDVI, VARI, WDRVI e SAVI), calculados a partir dos valores dos números digitais das imagens e dos valores estimados da reflectância. Para aquisição das imagens foi utilizado uma plataforma contendo duas câmeras digitais, uma sensível na região do visível (RGB) e a outra sensível na região do infravermelho próximo, esta plataforma foi acoplada a um balão inflado com gás hélio. Os índices de vegetação obtidos a partir dos valores dos números digitais das imagens só foram capazes de diferirem os tratamentos aos 70 dias após o plantio. Os índices obtidos pelos valores estimados da reflectância diferiram os tratamentos aos 34 e 70 dias após o plantio.

Termos para indexação: Sensoriamento remoto, manejo do solo, balão não tripulável.

(Received in january 23, 2012 and approved in march 30, 2012)

\section{INTRODUCTION}

Soil management and cultural treatments cause alterations in soil physical properties; therefore the study of soil physical quality is of extreme importance, once it is a component of great importance for agricultural production.

Strudley et al. (2008) reported that compaction is imminently linked to the development of plants and the physical quality of soil.
Excessive soil compaction, besides limiting the adsorption and/or absorption of nutrients, infiltration and redistribution of water and also gaseous exchanges (GUIMARÃES et al., 2002), may increase the $\mathrm{N}_{2} \mathrm{O}$ emission to the atmosphere (RUSER et al., 2006).

Remote sensing is one of the tools used in precision agriculture, in which the acquired images are transformed into vegetation indexes, which may be related to some variables of the studied culture (ABRAHÃO et al., 2009).

\footnotetext{
1Universidade Federal de Viçosa/UFV - Departamento de Engenharia Agrícola - 36.570-000 - Viçosa - MG -Brasil - daniel.mariano@ufv.br 2Universidade Federal de Viçosa/UFV - Departamento de Engenharia Agrícola -Viçosa - MG - Brasil

${ }^{3}$ Universidade Federal de Viçosa/UFV - Departamento de Fitotecnia - Viçosa - MG - Brasil

${ }^{4}$ Universidade Federal de Viçosa/UFV - Departamento de Solos - Viçosa - MG - Brasil

${ }^{5}$ Universidade Federal de Viçosa/UFV - Departamento de Estatística - Viçosa - MG - Brasil
} 
According to Yi et al. (2007) and Ramirez et al. (2010), remote sensing enables obtaining useful information for accompaniment and decision making in the management of agricultural cultures, once it makes possible the identification of agricultural areas and their dynamics.

Despite providing countless applications, precise links between the remote sensing variables and biophysical systems, are very complex, which Epiphanio et al. (1996) reports as great challenges in remote sensing.

The conventional image acquisition systems are expensive and hard to operate. However, Jesen et al. (2007) used a balloon system, unmanned, inflated with helium gas, and commercial cameras with filters in the visible and infrared areas, in order to minimize costs. Besides the advantage of being low cost, we highlight the easy handling and possibility of height control.

The vegetation indexes are mathematical models used to assess the vegetable coverage, which are usually correlated to some field-measured variables. These indexes can be calculated from the data of radiance, reflectance values or directly from the digital number of the images.

The hypothesis of this study is that it is possible to discriminate compacted soil areas using vegetation indexes, taking into consideration that plants may change their spectral properties in case the soil is compact.

Therefore, this work aimed to evaluate the use of vegetation indexes for discriminating areas with distinct soil compaction, obtained by different systems of soil management, for the culture of beans in different phenological phases, using a sub-orbital remote sensing system of low cost in obtaining the digital images.

\section{MATERIAL AND METHODS}

The experiment took place at an experimental area belonging to the Department of Crop Science of the Federal University of Viçosa, located in the city of Viçosa, MG, Brazil, at 20 45' 38" latitude South and 42 49' $30^{\circ}$ longitude West, at an altitude of $693 \mathrm{~m}$. The soil was classified as Dystrophic Red-Yellow Argisol according to the classification of Embrapa (2006), with mean declivity of $1 \%$.

In the experimental area, simple soil samples were collected comprised of a compound sample, in the range from 0 to $0.20 \mathrm{~m}$ deep. After receiving the results of the chemical and physical analysis, the recommendations were made for composting and plantation.

The treatments consisted of four soil management systems:, $\mathrm{CP}=$ Conventional planting, $(\mathrm{PC}=$ Plantio convencional), consisted of one plow and two harrowing, at a depth of $0.3 \mathrm{~m}$; $\mathrm{CM}-\mathrm{E}=$ minimum plantation, using a scarificator, at a depth of $0.25 \mathrm{~m}$; CM-G = Minimum Plantation, using a grade crusher-leveler and DP = Direct planting ( $\mathrm{PD}=$ Plantio direto $)$.

A common-bean species (Phaseolus vulgaris L.) was used, cultivar BRSMG Madrepérola, seeded on February $23^{\text {rd }}$ of 2011.

The seeder-composter was regulated to work at a spacing of $0.45 \mathrm{~m}$ between the lines, distributing 15 seeds per linear meter, placing the seed at $0.03 \mathrm{~m}$ deep. For the composting a dosage of $350 \mathrm{~kg} \mathrm{ha}^{-1}$ in the formulation NPK 8-28-16 was used.

For each experimental unit a soil density was determined using the volumetric ring method Embrapa (1997), in the range from 0 to $0.30 \mathrm{~m}$ depth, stratified at every $0.1 \mathrm{~m}$, in 03 replications.

For determining the soil resistance to penetration we used a geo-referenced penetrometer of the DLG brand; model PNT - 2000, with a type 2 cone tip with an area of $129 \mathrm{~mm}^{2}$. Samples were made from 15 points per experimental unit, at a maximum depth of $400 \mathrm{~mm}$, and the resistance to penetration was recorded every $10 \mathrm{~mm}$ depth.

We also collected deformed soil samples in each experimental unit to determine the water content, by gravimetric method in oven at $105^{\circ} \mathrm{C}$ for $24 \mathrm{~h}$.

The samples regarding soil density, soil resistance to penetration and level of water in soil were collected after planting.

Seven images were taken at days 27, 34, 41, 55, 62, 66 , and 77 after planting.

The image acquisition system was comprised of a balloon of the Skyhook Helikite brand (Figure 1) inflated with helium gas (99.999\% purity). This balloon is a combination of a balloon with a kite, which provides a

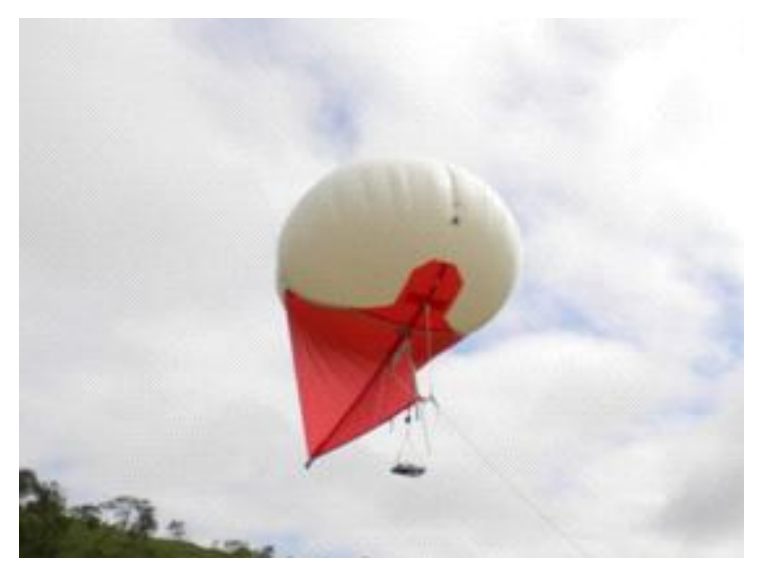

Figure 1 - Skyhook Helikite balloon. 
flight with stable direction and altitude, using helium gas and wind force as propulsion elements with guidance made with a rope.

The platform for image acquisition was composed of two digital cameras and a trigger system to activate the cameras.

Digital cameras of the FUJIFILM brand, model FinePix Z20fd, were used, which were activated simultaneously by a system of data transmission via radiofrequency, triggered by manual control (Figure 2). These cameras are equipped with CCD (charge-coupled device) of $1 / 2.5 "$. In one of the cameras the sensitivity limiting filter was removed from the infrared band (695 to $1050 \mathrm{~nm}$ ) and attached to an optic filter model RT-830 (725 to $1000 \mathrm{~nm}$ ) to acquire the images of the proximal infrared band. The cameras were configured to obtain images of 10 mega pixels.

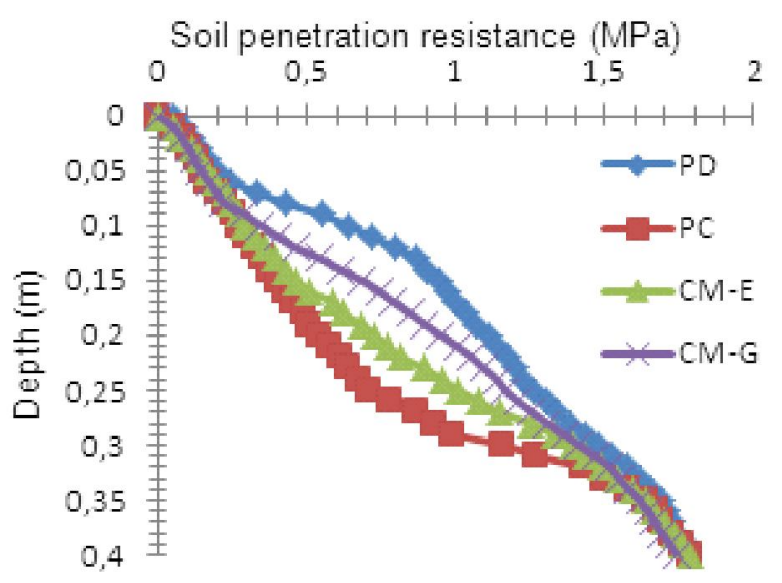

Figure 2-Soil penetration resistance, in function of depth.

For obtaining the images, the image acquisition set was approximately at $60 \mathrm{~m}$ high.

Due to interferences caused by lighting variation and targeting, the images were calibrated radiometrically. The calibration consists in correcting the radiometric values of the images in relation to a reference image (of known reflectance).

As reference three panels in different shades of gray were used placed in the center of the experimental area during image capturing.

To measure the reflectance of the panels a spectroradiometer, model FieldSpec ${ }^{\circledR}$ HandHeld $2^{\mathrm{TM}}$ ASD Inc, was used. It acts on the wavelengths comprised between 300 and $1100 \mathrm{~nm}$, with a spectral resolution of 1 $\mathrm{nm}$, composed o fiber optics with $25^{\circ}$ field of vision.
The images were calibrates in function of reflectance, through simple linear regression equations, were the adjustments were obtained from each spectral band (Equation 1).

$\hat{\mathrm{Y}}_{i j k}=\beta_{0}+\beta_{1} N C_{i j k}$

where,

$\hat{\mathrm{Y}}_{i j k}=$ Reflectance in line $i$ and column $j$ of band $k$;

$\beta_{0}=$ Constant of regression;

$\beta_{1}=$ Coefficient of regression; and

$N C_{i j k}=$ Level of gray at line $i$ and column $j$ of band $k$, dimensionless.

The processing of the digital images was made in the Matlab ${ }^{\circledR}$ computer system with elimination of the edges and then calculation of the mean pixel values of each band (RGB and NIR) the spectral indexes were obtained digital number values of the images as well as the estimated values of reflectance, according to the Equations:

$$
\begin{aligned}
& N D V I=\frac{(N I R-R)}{(N I R+R)} \\
& R S=\frac{R}{N I R} \\
& V A R I=\frac{G-R}{G+R-B} \\
& N D V I=\frac{N I R-G}{N I R+G} \\
& V A R I=\frac{G-R}{G+R-B} \\
& S A V I=\frac{N I R-R}{N I R+R+L} .(1+L)
\end{aligned}
$$

where,

$N D V I=$ Normalized difference vegetation index (ROUSE et al.,1974);

$R S=$ Simple ratio vegetation index, proposed by (PEARSON \& MILLAR, 1972);

WDRVI = Dynamic vegetation index of wide range (GITELSON, 2004);

$G N D V I=$ Normalized difference vegetation index using green band (GITELSON et al.,1996); 
$V A R I=$ Atmosphere resistant vegetation index at the visible region (GITELSON et al., 2003);

$S A V I=$ Soil adjusted vegetation index (HUETE, 1988);

$B=$ Mean image value in the blue band;

$G=$ Mean image value in the green band;

$R=$ Mean image value in the red band;

$N I R=$ Mean image value in the proximal infrared band; $a=$ Coefficient of weightage, values of $0.05,0.1$ and 0.2 ; $L=$ Coefficient of weightage, values of 0.25 and 1.0 .

The treatments were made in randomized block design with 6 replications, totaling 24 experimental plots.

The experimental plots had $2.5 \times 20 \mathrm{~m}$, which enabled the planting of 5 lines for each experimental unit. The lateral lines of each plot were excluded in order to disregard the edge effect at the moment of data acquisition. All of the statistical analyses were made using the software SAS 9.2.

\section{RESULTSAND DISCUSSION}

Table 1 presents the results of soil density. It was seen in range $0-0.10 \mathrm{~m}$ depth that the PD treatment presented higher density $\left(1.32 \mathrm{~g} \mathrm{~cm}^{-3}\right)$, followed by treatments CM-G $\left(1.28 \mathrm{~g} \mathrm{~cm}^{-3}\right), \mathrm{CM}-\mathrm{E}\left(1.17 \mathrm{~g} \mathrm{~cm}^{-3}\right)$ and PC $\left(1.06 \mathrm{~g} \mathrm{~cm}^{-3}\right)$. The PD treatment did not differ statistically from treatments CM-G and CM-E, differing only from PC.

At the depth range $0.10-0.20 \mathrm{~m}$, only the PC treatment differed from the other treatments. On the depth layer $0.20-0.30 \mathrm{~m}$, on the other hand, despite the PC treatment has kept an inferior mean from the other treatments, no significant difference was found.

As expected, the action of the soil mobilization implements altered the soil density in several studied depths. The direct planting system, with a minimally mobilized soil, presented the highest density values, agreeing with the reports by Stone and Silveira (2001), characterizing higher soil compaction in relation to the other preparation systems.

Guimarães et al. (2002) verified that the values of soil density above $1.2 \mathrm{~g} \mathrm{~cm}^{-3}$, negatively affected the development of the radicular system and the aerial part of the bean plant.

Figure 2 shows the mean values of soil penetration resistance. At the moment of soil collection, it presented a water level equals to $0.19 \mathrm{~kg} \mathrm{~kg}^{-1}$.

As observed, the PD treatment presented values of soil mechanic resistance to penetration above the other treatments in the entire analyzed profile. The treatments PC, CM-E and CM-G presented very close values in the layer $0-0.08 \mathrm{~m}$, from this layer until $0.33 \mathrm{~m}$ the $\mathrm{CM}-\mathrm{G}$ treatment had the tendency to present the highest values of resistance to penetration, in relation to treatments CM$\mathrm{E}$ and $\mathrm{PC}$, approximating their values of resistance to penetration in the range of $0.33-0.40 \mathrm{~m}$ in depth.

The color digital images (RGB) and infrared were obtained at seven distinct times $(27,34,41,55,62,66$ and 70 days after planting).

After retrieving the images from the acquisition platform, the vegetation indexed were calculated with the values of the digital numbers and also with the estimated values of reflectance, presented in Table 2 and 3. For obtainning the vegetation indexes, only the images that contained the entire experimentation area were used, as seen in figure 3 .

Tables 2 and 3 present the statistically significant results found in this study.

As presented in table 2, a distinction between the treatment effects by the indexes obtained by the values of digital numbers was only possible 70 days after planting.

With the indexes, NDVI, GNDVI, WDRVI $(\mathrm{a}=0.05)$, WDRVI $(a=0.1)$, WDRVI $(a=0.2)$ and SAVI $(\mathrm{L}=0.25)$ it was possible to distinguish two groups: one of the groups composed of treatments PD, PC and CM-G and the other group by treatments $\mathrm{CM}-\mathrm{E}$ and $\mathrm{PC}$, being possible to isolate the effects of treatment CM-E from treatments PD and CMG. Indexes RS and VARI also generated two groups: one, grouping the treatments PD, PC and CM-G and in the other group PC, CM-E and CM-G, statistically differing the treatment $\mathrm{PD}$ from CM-E.

Table 1 - Mean values of soil density $\left(\mathrm{g} \mathrm{cm}^{-3}\right)$.

\begin{tabular}{cccc}
\hline \multirow{2}{*}{ Treatments } & \multicolumn{3}{c}{ Depth layer $(\mathrm{m})$} \\
\cline { 2 - 4 } & $0.0-0.10$ & $0.10-0.20$ & $0.20-0.30$ \\
\hline PD & $1.32 \mathrm{a}$ & $1.43 \mathrm{a}$ & $1.42 \mathrm{a}$ \\
PC & $1.06 \mathrm{~b}$ & $1.23 \mathrm{~b}$ & $1.33 \mathrm{a}$ \\
CM-E & $1.17 \mathrm{ab}$ & $1.41 \mathrm{a}$ & $1.42 \mathrm{a}$ \\
CM-G & $1.28 \mathrm{a}$ & $1.43 \mathrm{a}$ & $1.43 \mathrm{a}$ \\
\hline CV $(\%)$ & 11.55 & 8.67 & 8.11 \\
\hline
\end{tabular}

The means followed by at least one letter, do not differ from each other, at a level of $5 \%$ probability by the Tukey test. 
Table 2 - Vegetation indexes obtained by the values of the digital numbers.

\begin{tabular}{ccccccccccc}
\hline Collection & Treatments & NDVI & \multirow{2}{*}{ RS } & GNDVI & VARI & $\begin{array}{l}\text { WDRVI } \\
(\mathrm{a}=0.05)\end{array}$ & $\begin{array}{c}\text { WDRVI } \\
(\mathrm{a}=0.1)\end{array}$ & $\begin{array}{l}\text { WDRVI } \\
(\mathrm{a}=0.2)\end{array}$ & $\begin{array}{c}\text { SAVI } \\
(\mathrm{L}=0.25)\end{array}$ & $\begin{array}{c}\text { SAVI } \\
(\mathrm{L}=1.0)\end{array}$ \\
\hline \multirow{3}{*}{$70 \mathrm{DAP}$} & $\mathrm{PD}$ & $0.25 \mathrm{a}$ & $0.60 \mathrm{~b}$ & $0.16 \mathrm{a}$ & $0.14 \mathrm{a}$ & $-0.85 \mathrm{a}$ & $-0.71 \mathrm{a}$ & $-0.50 \mathrm{a}$ & $0.31 \mathrm{a}$ & $0.50 \mathrm{a}$ \\
& $\mathrm{PC}$ & $0.22 \mathrm{ab}$ & $0.64 \mathrm{ab}$ & $0.14 \mathrm{ab}$ & $0.12 \mathrm{ab}$ & $-0.85 \mathrm{ab}$ & $-0.73 \mathrm{ab}$ & $-0.52 \mathrm{ab}$ & $0.27 \mathrm{ab}$ & $0.44 \mathrm{ab}$ \\
& $\mathrm{CM}-\mathrm{E}$ & $0.20 \mathrm{~b}$ & $0.67 \mathrm{a}$ & $0.12 \mathrm{~b}$ & $0.10 \mathrm{~b}$ & $-0.86 \mathrm{~b}$ & $-0.74 \mathrm{~b}$ & $-0.54 \mathrm{~b}$ & $0.24 \mathrm{~b}$ & $0.39 \mathrm{~b}$ \\
& $\mathrm{CM}-\mathrm{G}$ & $0.24 \mathrm{a}$ & $0.62 \mathrm{ab}$ & $0.15 \mathrm{a}$ & $0.13 \mathrm{ab}$ & $-0.85 \mathrm{a}$ & $-0.72 \mathrm{a}$ & $-0.51 \mathrm{a}$ & $0.29 \mathrm{a}$ & $0.47 \mathrm{a}$ \\
\hline
\end{tabular}

Means followed by at least one letter do not differ from each other, at a $5 \%$ probability level, by the Tukey test.

Table 3 - Vegetation Indexes obtained by the estimated reflectance values.

\begin{tabular}{|c|c|c|c|c|c|c|c|c|c|c|}
\hline Collection & Treatments & NDVI & $\mathrm{RS}$ & GNDVI & VARI & $\begin{array}{l}\text { WDRVI } \\
(\mathrm{a}=0.05)\end{array}$ & $\begin{array}{l}\text { WDRVI } \\
(\mathrm{a}=0.1)\end{array}$ & $\begin{array}{l}\text { WDRVI } \\
(\mathrm{a}=0.2)\end{array}$ & $\begin{array}{c}\text { SAVI } \\
(\mathrm{L}=0.25)\end{array}$ & $\begin{array}{c}\text { SAVI } \\
(\mathrm{L}=1.0)\end{array}$ \\
\hline \multirow{5}{*}{34 DAP } & PD & $1.12 \mathrm{a}$ & $-0.06 b$ & $0.89 \mathrm{a}$ & $0.90 \mathrm{a}$ & $277.60 \mathrm{a}$ & $5.59 \mathrm{a}$ & $1.84 \mathrm{a}$ & $1.13 \mathrm{a}$ & $1.17 \mathrm{a}$ \\
\hline & $\mathrm{PC}$ & $1.07 \mathrm{a} \mathrm{b}$ & $-0.03 \mathrm{a} \mathrm{b}$ & $0.86 \mathrm{a}$ & $0.76 \mathrm{ab}$ & $-6.60 \mathrm{a}$ & $2.22 \mathrm{a}$ & $1.42 \mathrm{~b}$ & $1.10 \mathrm{a}$ & $1.16 \mathrm{ab}$ \\
\hline & CM-E & $1.08 \mathrm{a} \mathrm{b}$ & $-0.04 \mathrm{a} \mathrm{b}$ & $0.87 \mathrm{a}$ & $0.70 \mathrm{~b}$ & $-19.81 \mathrm{a}$ & $2.31 \mathrm{a}$ & $1.46 \mathrm{a} \mathrm{b}$ & $1.10 \mathrm{a}$ & $1.15 \mathrm{a}$ \\
\hline & CM-G & $1.06 \mathrm{~b}$ & $-0.02 \mathrm{a}$ & $0.85 \mathrm{a}$ & $0.68 \mathrm{~b}$ & $8.43 \mathrm{a}$ & $1.99 \mathrm{a}$ & $1.36 \mathrm{~b}$ & $1.08 \mathrm{a}$ & $1.11 \mathrm{a}$ \\
\hline & $\mathrm{CV}(\%)$ & 4.34 & 56.63 & 3.99 & 23.64 & 561.77 & 108.07 & 22.53 & 4.68 & 6.61 \\
\hline \multirow{5}{*}{70 DAP } & PD & $0.49 \mathrm{~b}$ & $0.34 \mathrm{a}$ & $0.62 \mathrm{~b}$ & $0.34 \mathrm{a}$ & $-0.74 b$ & $-0.55 b$ & $-0.27 b$ & $1.08 \mathrm{~b}$ & $-1.29 \mathrm{a}$ \\
\hline & $\mathrm{PC}$ & $0.52 \mathrm{~b}$ & $0.31 \mathrm{a}$ & $0.65 \mathrm{~b}$ & $0.21 \mathrm{~b}$ & $-0.71 b$ & $-0.51 b$ & $-0.21 b$ & $1.27 \mathrm{a} \mathrm{b}$ & $-1.20 \mathrm{a}$ \\
\hline & CM-E & $0.60 \mathrm{a}$ & $0.24 \mathrm{~b}$ & $0.70 \mathrm{a}$ & $0.15 \mathrm{~b}$ & $-0.66 \mathrm{a}$ & $-0.42 \mathrm{a}$ & $-0.10 \mathrm{a}$ & $1.58 \mathrm{a}$ & $-1.24 \mathrm{a}$ \\
\hline & CM-G & $0.51 \mathrm{~b}$ & $0.32 \mathrm{a}$ & $0.63 \mathrm{~b}$ & $0.26 \mathrm{a} \mathrm{b}$ & $-0.73 b$ & $0.52 \mathrm{~b}$ & $-0.23 b$ & $1.17 \mathrm{a} \mathrm{b}$ & $-1.27 \mathrm{a}$ \\
\hline & $\mathrm{CV}(\%)$ & 10.49 & 15.00 & 6.22 & 40.39 & 6.05 & 12.87 & 39.27 & 22.86 & 15.92 \\
\hline
\end{tabular}

Means followed by at least one letter did not differ from each other, at $5 \%$ probability level, by the Tukey test.

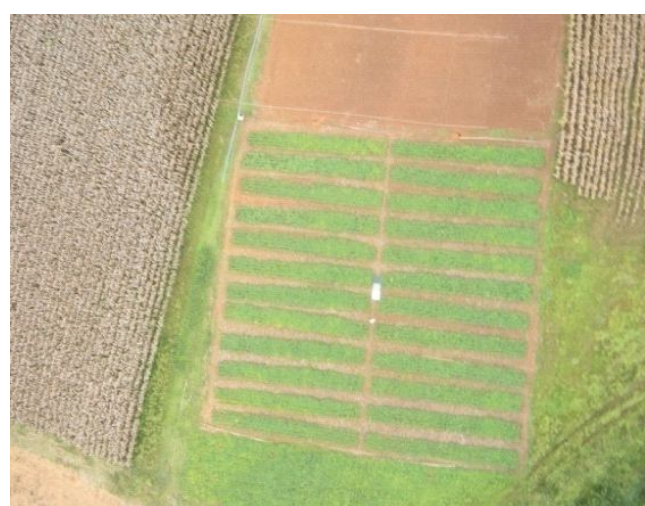

(A)

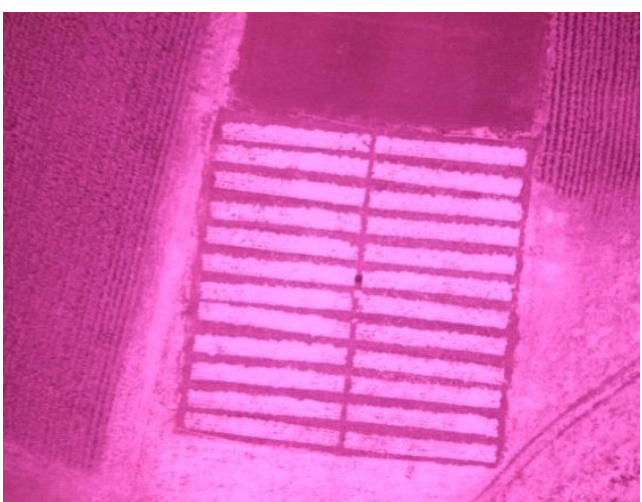

(B)

Figure 3 - (A) Image in RGB and (B) Image in infrared.

With the indexes obtained from the estimated values of reflectance (Table 3), it was possible to distinguish the treatments at 34 and 70 days after planting.
At day 34 after planting, the indexes NDVI and RS discriminated the treatment PD from the treatment CM-G. The VARI index discriminated treatment PD from treatments 
CM-E and CM-G. The WDRVI index, on the other hand, $(a=0.2)$ discriminated the PD treatment from treatments PC and CM-G.

With indexes NDVI, GNDVI, WDRVI $(\mathrm{a}=0.05)$, WDRVI $(a=0.1)$, WDRVI $(a=0.2)$ and SAVI $(\mathrm{L}=0.25)$ it was possible to distinguish two groups: one of the groups composed by treatments PD, PC and CM-G and the other group composed by treatments CM-E and PC, it was possible to isolate the effect of treatment CM-E from treatments PD and CM-G. The indexes RS and VARI have also generated two groups, grouping treatments $\mathrm{PD}, \mathrm{PC}$ and $\mathrm{CM}-\mathrm{G}$ and in the other group PC, CM-E e CM-G, statistically differing the treatment $\mathrm{PD}$ from CM-E.

At 70 days after planting, the indexes NDVI, RS, GNDVI, WDRVI $(\mathrm{a}=0.05)$, WDRVI $(\mathrm{a}=0.1)$, WDRVI $(\mathrm{a}=0.2)$, formed two groups, isolating treatment CM-E from the other treatments. The index VARI differed the PD treatment from $\mathrm{CM}-\mathrm{E}$ and $\mathrm{PC}$. The index SAVI $(\mathrm{L}=0,25)$ discriminated the PD treatment from CM-E.

The distinction that occurred 70 days after planting was due to the physiological phase of the culture, known as R8 pod filling stage, where there is a greater extraction of minerals and water from the soil, therefore, it was possible to evidence the effects of the treatments.

Indexes which were obtained from estimated values of reflectance, presented to be more sensitive to discriminate treatments in relation to the ones obtained from values of digital number.

\section{CONCLUSIONS}

The proposed methodology demonstrated to be capable of differing levels of soil compaction.

With use of indexes obtained from the values of digital numbers, differences between levels of soil compaction at 70 days after planting were found.

With indexes obtained from the estimated values of reflectance, differences between the levels of soil compaction were detected at 34 and 70 days after planting were found.

\section{REFERENCES}

ABRAHÃO, S. A. et al. Índices de vegetação de base espectral para discriminar doses de nitrogênio em capimtanzânia. Revista Brasileira de Zootecnia, v.38, n.9, p. 1637-1644. 2009.

EMBRAPA. Centro Nacional de Pesquisa de Solos. Manual de métodos de análise de solo. 2. ed. Rio de Janeiro, 1997.212p.
EMBRAPA. Centro Nacional de Pesquisa de Solos. Sistema Brasileiro de Classificação de Solos. Rio de Janeiro, 2006. 306p.

EPIPHANIO, J. C. N. et al. Índice de vegetação no sensoriamento remoto da cultura do feijão. Pesquisa Agropecuária Brasileira, Brasília, v.31, n.6, p.445-454, 1996.

GITELSON, A. A. Wide Dynamic Range Vegetation Index for remote quantification of biophysical characteristics of vegetation. Journal of Plant Physiology. v.161, n. 2, p.165-173, 2004.

GITELSON, A. A. et al. Remote estimation of leaf area index and green leaf biomass in maize canopies.

Geophysical Research Letters, v.30, n.5, 2003.

GITELSON, A. A.; KAUFMAN, Y. J.; MERZLYAK, M. N. Use of a green chanel in remote sensing of global vegetation from EOS-MODIS. Remote Sensing of Enviroment, v.58, n. 3, p.289-298, 1996.

GUIMARÃES, C. M.; STONE, L. F.; MOREIRA, A. A. J. Compactação do solo na cultura do feijoeiro. II: efeito sobre o desenvolvimento radicular e da parte aérea. Revista Brasileira de Engenharia Agrícola e Ambiental, Campina Grande, v.6, n. 2, p.213-218, 2002.

HUETE, A. R. A soil-adjusted vegetation index (SAVI). Remote Sensing of Enviroment, v.25, n. 3, p.295-309, 1988.

JENSEN, T. et al. Detecting the attributes of a wheat crop using digital imagery acquired from a low-altitude platform. Computers and Electronics in Agriculture, v.59, n. 1-2, p.66-77, 2007.

PEARSON, R. L.; MILLER, R. D. Remote mapping of starting crop biomass for estimation of the productivity of the shortgrass praine. In: INTERNATIONAL SYMPOSIUM ONREMOTE SENSINGOF ENVIROMENT, 8., Ann Arbor, 1972. Proceedings... Ann Arbor: MI, ERIM, 1972. v.2, p.1355-1373.

RAMIREZ, G. M.; ZULLO JUNIOR, J. Estimativa de parâmetros biofísicos de plantios de café a partir de imagens orbitais de alta resolução espacial. Engenharia Agrícola, vol.30, n.3, p.468-479, 2010. 
ROUSE, J. W. et al. Monitoring the vernal advancement of retrogradation (greenwave effect) of natural vegetation. NASA/GSFC, Type III, Final Report, Greenbelt, MD, 1974, 371p.

RUSER, R. et al. Emission of $\mathrm{N}_{2} \mathrm{O}, \mathrm{N}_{2}$ and $\mathrm{CO}_{2}$ from soil moisture and rewetting. Soil Biology and Biochemistry, v.38, n. 2, p.263-274, 2006.

STONE, L. F.; SILVEIRA, P. M. Efeitos do sistema de preparo e da rotação de culturas na porosidade e densidade do solo. Revista Brasileira de Ciência do Solo, v.25, p.395-401, 2001.

STRUDLEY,M.W.; GREEN,T.R.;ASCOUGH, J.C.Tillage effects on soil hydraulic properties in space and time: state of the science. Soil and Tillage Research, v.99, n. 1, p.4-48, 2008.

YI, J. L. R.; SHIMABUKURO, Y. E.; QUINTANILHA, J. A. Identificação e mapeamento de áreas de milho na região sul do Brasil utilizando imagens MODIS. Engenharia Agrícola, Jaboticabal, v.27, n.3, p. 753-763, 2007. 